\title{
Influence of glaze ice storms on growth rates of loblolly pine Pinus taeda and shortleaf pine Pinus echinata in the Southern Appalachian Piedmont
}

\author{
David J. Travis, Vernon Meentemeyer \\ Department of Geography, University of Georgia, Athens, Georgia 30602, USA
}

\begin{abstract}
Data on ring-width increments taken from loblolly Pinus taeda L. and shortleaf pines Pinus echinata Mill. were analyzed to determine the degree of impact by ice storms on radial growth at 3 sites in the Southern Appalactian Piedmont. For each of the 3 sites a dendroclimatological model of the temperature and precipitation signal in annual ring widths was produced. Residuals from each model were regressed against the timing (date) and severity (ice accumulation) of ice storms. Information on the timing of an ice storm increased the $\mathrm{R}^{2}$ for the shortleaf stand by an additional $0.19(0.25$ to 0.43 ) Storms late in the winter produced the greatest reductions in ring widths. For the 2 loblolly sites, ice storm severity increased the explained variance by $0.11(0.35$ to 0.46$)$ and by $0.10(0.39$ to 0.49$)$, respectively. Each severe ice storm occurrence was associated with a large negative residual. Radial growth reduction appears to be confined to the immediate growing season following the storm. No ice storm signals could be found for the second and third years following a storm, nor did the trees show any permanent structural damage. The models presented in this study suggest that the economic impacts of an ice storm, or the cumulative effects of ice storms on a stand, can be estimated.
\end{abstract}

\section{INTRODUCTION}

Dendrochronological studies have produced much information about the relationships between the growth of trees and their environments. Traditionally, correlations between annual tree-ring increments and recorded temperature and precipitation have been examined (Hughes et al, 1982). Typically, in the conifer forests of eastern North America, between 20 and $45 \%$ of the variance in ring widths has been attributed to the variation of these climate variables (Dewitt $\&$ Ames 1978). Clearly there are variables other than temperature and precipitation which affect tree growth. Some of these factors are biotic (e.g. competition) but other factors may be episodic climatic events such as ice storms.

Damage to trees from glazing has been well documented (e.g. Bennett 1959, Lemon 1961). Conifers appear to be especially vulnerable because many needles remain on trees throughout the winter months (Shepard 1975). This provides additional leaf area for ice accumulation which can cause the weight of branches and needles to be as much as 30 times their normal weight and 10 times their normal size (Baxter 1943). The added weight may lead to damage by at least 3 primary mechanisms - stripping of limbs, bending and/or breaking of crowns, and root damage resulting from excessive bending of the trunk (Lemon 1961). The first 2 mechanisms may result in mortality or permanent damage to the physiological growth mechanisms. The latter is likely to only produce a short-term effect on growth.

Only healthy trees with no obvious deformities were selected for sampling. However, each stand did contain a number of trees which showed permanent icestorm damage (Travis et al. 1991). When ice storms occur all surfaces are coated over a widespread area. We may, therefore, assume our sample trees were at least temporarily damaged by losses of small branches and needles and overall reduction of photosynthetic area. It is this 'temporary' loss in stem increment which we are quantifying here. 


\section{Objectives}

The goal of this study was to examine the influence of ice storms on radial growth rates of trees from selected stands of loblolly pine Pinus taeda L. and shortleaf pine Pinus echinate Mill. in the southeastern United States. Trees from 3 separate sites -2 from north central Georgia and 1 from northwestern South Carolina were analyzed. All trees are located in a region which on average experiences significant glaze ice once every 5 yr (McKeller 1942).

We present a quantitative assessment of the effects of ice storms on the temporary reduction of radial growth in respect to their severity (ice accumulation) and timing (date). We hypothesize that storms occurring late in the winter or in early spring produce a greater loss in radial growth than those which occur in the early winter months. It is likely that storms occurring during late winter will damage trees that are no longer in dormancy. Thus damage should be greater, as many trees may have already begun earlywood growth.

\section{MATERIALS AND METHODS}

Study sites and chronologies. A tree-ring chronology was developed for each species at each of the 3 sites (Fig. 1). Each chronology was analyzed using established methods for the recognition of climate signals (Phipps 1985). All trees were members of naturally regenerated stands growing on a variety of slopes and orientation. Two of the study sites are located in Georgia (Athens and Greensboro) and one is in South Carolina (Clemson). All are located in the Appalachian

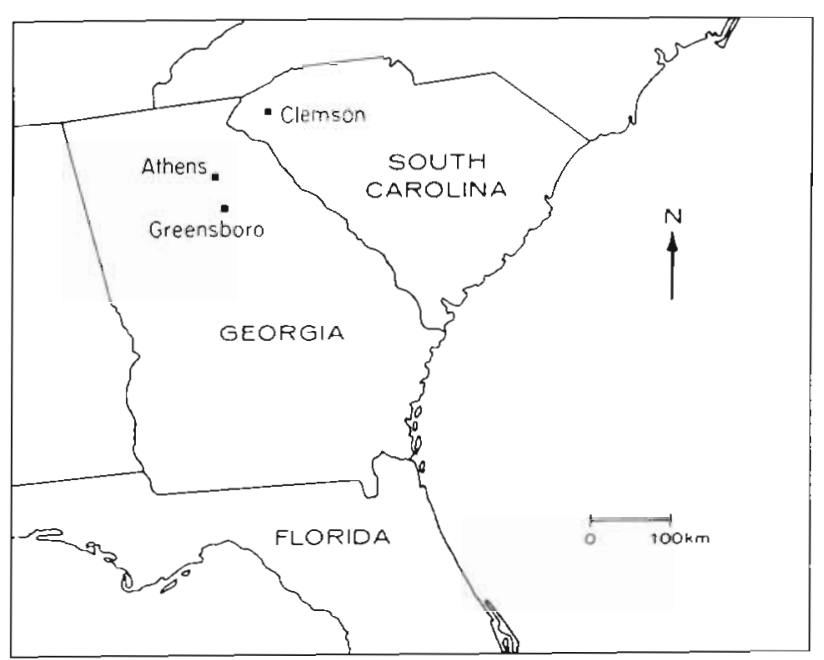

Fig. 1. Location of study sites, southeastern USA
Table 1. Geographical and biological information for each of the study sites and the number of trees cored

\begin{tabular}{|lccc|}
\hline Site & Athens & Greensboro & Clemson \\
\hline Latitude & $33.57^{\circ} \mathrm{N}$ & $33.42^{\circ} \mathrm{N}$ & $34.41^{\circ} \mathrm{N}$ \\
Longitude & $83.19^{\circ} \mathrm{W}$ & $83.16^{\circ} \mathrm{W}$ & $82.49^{\circ} \mathrm{W}$ \\
Elevation & $245 \mathrm{~m}$ & $220 \mathrm{~m}$ & $250 \mathrm{~m}$ \\
Tree species & Loblolly & Loblolly & Shortleaf \\
No. of trees & 22 & 25 & 24 \\
$\begin{array}{l}\text { Tree-ring } \\
\text { chronology }\end{array}$ & $1921-1986$ & $1910-1985$ & $1684-1973$ \\
Ice storm & $1937-1986$ & $1926-1985$ & $1915-1973$ \\
chronology & & & \\
\hline
\end{tabular}

Piedmont region, a transition zone between the Appalachian mountains and the coastal plain. Athens and Greensboro were treated independently because ice storms have been reported in bands of $30 \mathrm{~km}$ or less (Turner \& Marriott 1988). Table 1 lists the sample size for each species respectively, as well as the approximate elevation and geographic coordinates. The Athens data were obtained from Grissino-Mayer et al. (1989) and the Clemson data from Dewitt \& Ames (1978). The Greensboro data were collected by the authors.

Data collection techniques. All trees selected for coring were dominants or co-dominants located within closed stands and on slopes of $30^{\circ}$ or less. Two cores were taken from opposite sides of each tree at breast height $(1.4 \mathrm{~m})$. Although each chronology was developed for separate studies, standard dendrochronological methods were used in all cases (e.g. Stokes \& Smiley 1968, Fritts 1976, Phipps 1985). In addition, the customary procedures for handling cores, their measurement, standardization and crossdating were performed. Arima models (Box \& Jenkins 1976), which aid in reducing autocorrelation, were fitted to the Greensboro and Athens data. The details of these procedures are presented in Travis (1989).

An ice storm chronology was developed for each study site. Only 'significant' ice storms were included for study: events which produced a layer of ice at least $12.5 \mathrm{~mm}$ thick. Previous research has reported that storms of less intensity produce little damage to pine species (e.g. Brender \& Romancier 1965, Goebel \& Deitschman 1967). In addition, small juvenile trees are more flexible than mature trees and have short branches which are less likely to accumulate damaging amounts of ice (Lemon 1961. Hebb 1971). For this reason ice storms that occurred during the first 15 yr of each chronology were not included.

To determine significant ice storm events in the 3 study areas during the appropriate periods, several 
sources of information were consulted. Initially monthly climatic summaries published for Georgia and South Carolina by the National Weather Service (NWS) were examined. Any ice storms were noted and then confirmed through back issues of newspapers. Because ice storms often disrupt electrical power service, a final confirmation was obtained through a check of records at Georgia and South Carolina Power offices.

In addition to determining the dates on which ice storms occurred, the severity, based upon ice accumulation totals on surface objects (i.e. trees, power lines, etc.), was obtained from the same sources. Often it was not possible to determine an exact value for accumulation. General ranges of values were sufficient, however, to place into an 'accumulation' category. Each storm was classified as either minor (12.5 to $25 \mathrm{~mm})$, moderate (25 to $37.5 \mathrm{~mm}$ ), major $(37.5$ to $50 \mathrm{~mm}$ ) or severe (50 $\mathrm{mm}$ or more). It was assumed that the ice accumulation reported with each storm was indicative of that which accumulated on our sample trees. The timing of each storm was noted by the day number of its occurrence. All storms occurred between 1 December and 31 March, and these dates were listed as Days 1 and 121, respectively (in non-leap years). Each storm was assigned a number between 1 and 121 with the higher numbers representing the later storm occurrences.

Data analysis. Before analyzing the influences of any disturbance upon growth of trees it is first necessary to account for the influences of temperature and precipitation (Swetnam 1987). Multiple regression techniques were used to regress climate variables against ringwidth data from each chronology.

Data on monthly temperature and precipitation (1895 to 1986) were obtained from the National Climate Data Center (NCDC) for the north-central and northwestern South Carolina climatic divisions. Division level data were used rather than single station values because previous studies have shown that such 'regional' data provide much better results in regression analyses using tree-ring data (Lawson et al. 1980, Blasing et al. 1981, Grissino et al. 1989). Monthly data covering the 16 mo period extending from the current September back to March of the previous year were regressed against the ring widths of each growing season. In addition, monthly data were combined into seasonal values. The 'best' model was achieved through stepwise regression with candidate climate variables only entered if they were significant at the 0.05 level.

The residual values from the best climate model for each of the sites are first presented and analyzed visually. Years having ring widths narrower than predicted by climate (i.e. negative values) may have had damaging ice storms during the previous winter.
To quantitatively test the ice storm hypotheses, the severity and timing of each storm were included in a regression analysis in which ring-width residuals formed the dependent variable. Severity values were listed by number from 1 to 4 which ranged from minor to severe with zero entered into the data set when a storm did not occur. The timing variable was listed in numerical form between 1 and 121 as explained previously. Storms occurring in December were correlated against ring-width values of the following year Data from the entire period (other than the first $15 \mathrm{yr}$ ) covered by each chronology were used in the regression procedure. Information on ice storms prior to 1915 was not available. At Greensboro, sampling error caused primarily by damage during coring to the most recent rings required the years from 1986 to 1988 to be eliminated from the data set.

These models were developed to demonstrate the strength of the relationship between known ice storm events and stem-increment reduction. Unlike most dendroclimatic studies, no efforts were made to predict or 'reconstruct' past (unknown) ice storms.

\section{RESULTS}

\section{The Clemson chronology}

The Clemson chronology was developed from 24 shortleaf pine and originally extended from 1684 to 1973 (Dewitt \& Ames 1978). Only the years between 1915 and 1973 were analyzed here. Eq. (1) is the best explanatory model based on monthly temperature and precipitation. Variables do not violate rules for autocorrelation and are listed in order of significance. All models are significant at the 0.01 level. The model is:

$$
\begin{aligned}
\text { RWI }= & 118.89-1.997 \text { CJLP }-1.618 \text { PAP } \\
& -1.921 \text { PJP }+1.240 \text { CJNP }
\end{aligned}
$$

$$
\left(R^{2}=0.25\right)
$$

where RWI = predicted ring-width residual index for each year; CJLP = current July precipitation total $(\mathrm{cm})$; $\mathrm{PAP}=$ previous August precipitation PJP $=$ previous June precipitation; and CJNP = current January precipitation.

Twelve significant ice storms occurred in the Clemson area during the $59 \mathrm{yr}$ study period (Table 2). Fig. 2. demonstrates that 9 of 12 'ice storm years' had smaller than expected ring widths as indicated by the negative residuals. The darkened circles indicate the occurrence of an ice storm the previous winter. Each of the 6 largest negative residuals occurred during a year when an ice storm was reported. Residuals were re- 
Table 2. Severity and timing of ice storms for Clemson, South Carolina, during the period 1915 to 1973

\begin{tabular}{|c|c|}
\hline Date & Severity \\
\hline $25 \mathrm{Jan} 1921$ & 3. major \\
\hline $23 \mathrm{Jan} 1923$ & 2 , moderate \\
\hline $17 \operatorname{Dec} 1932$ & 2, moderate \\
\hline 7 Jan 1940 & 1, minor \\
\hline 14 Feb 1944 & 2. moderate \\
\hline 25 Dec 1945 & 3. major \\
\hline 9 Feb 1948 & 4 , severe \\
\hline $19 \operatorname{Jan} 1955$ & 1, minor \\
\hline 4 Feb 1961 & 1, minor \\
\hline 31 Dec 1963 & 2 , moderate \\
\hline $30 \mathrm{Jan} 1965$ & 1, minor \\
\hline 7 Jan 1973 & 1, minor \\
\hline
\end{tabular}

gressed against the date of an ice storm (TIM) and stom severity (SEV); however, only TIM produced a significant relationship $\left(\mathrm{R}^{2}=0.25\right)$. Because $75 \%$ of the variance in the ring widths was unexplained in Eq. (1), this suggests that an additional 18 to $19 \%$ of the variance in ring widths can be explained solely by ice storms.

A model which includes ice storms is as follows:

$$
\begin{aligned}
\mathrm{RWI}= & 123.858+1.209 \text { CJLP }-0.271 \mathrm{TIM} \\
& -1.799 \text { PAP }-1.586 \text { PJP }-2.525 \text { CJNP }
\end{aligned}
$$

$$
\left(R^{2}=0.43\right)
$$

where all variables are as previously defined. The timing of ice storms is the second most important explanatory variable resulting in an increase of total explained variance from 25 to $43 \%$. Storm severity was not significant.

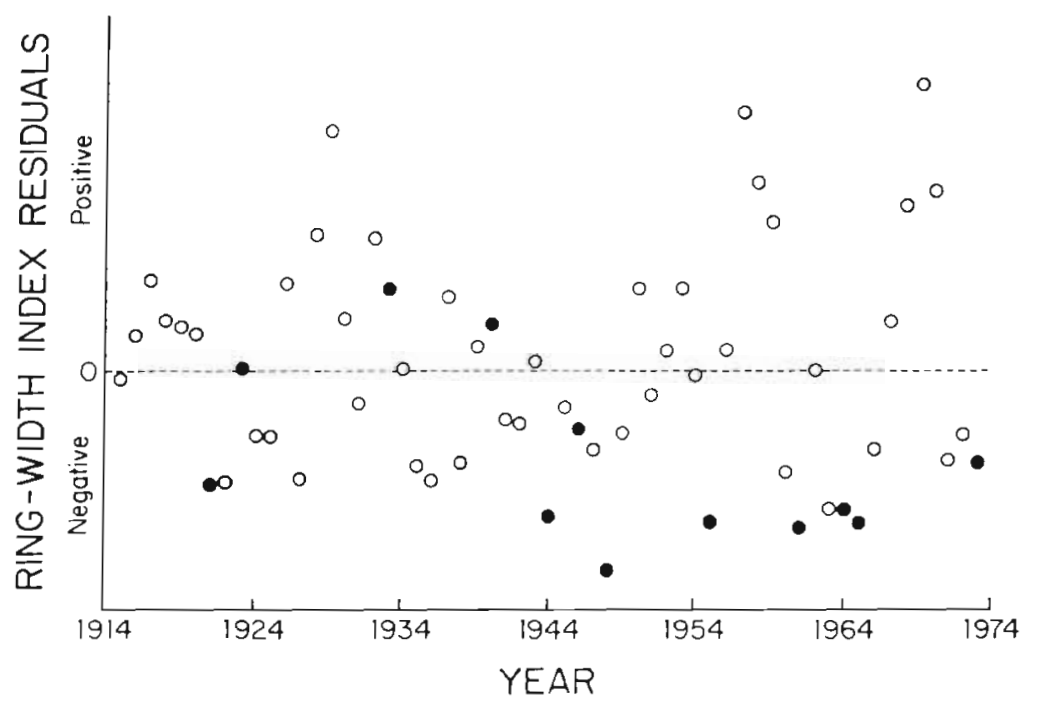

Fig. 2. Ring-width index residuals from Eq. (1.) (Clemson, shortleaf)
Cores taken from 25 loblolly pine near Greensboro spanned the period from 1910 to 1988 . The relationship with monthly temperature and precipitation for the Greensboro trees is expressed by the model:

$$
\begin{aligned}
\mathrm{RWI} & =2.53+0.018 \mathrm{CAP}+0.036 \mathrm{CMT} \\
& -0.035 \mathrm{CJLT}+0.026 \mathrm{PNP}+0.016 \mathrm{CMP} \\
\left(\mathrm{R}^{2}=\right. & 0.35)
\end{aligned}
$$

where $\mathrm{CAP}=$ current August precipitation; $\mathrm{CMT}=$ current March temperature; CJLT = current July precipitation; PNP = previous November precipitation; and CMP = current March precipitation

Thirteen ice storms occurred in the Greensboro area during the period from 1926 to 1985 (Table 3). Ten of the 13 storms occurred during years in which ring widths were narrower than predicted (Fig. 3). The 2 greatest negative residuals are both associated with years in which either a major (1940) or a severe (1979) storm occurred. We are unable to provide an explanation for the outlier seen in 1978.

All residuals were regressed against storm timing and severity but only severity produced a significant relationship $\left(R^{2}=0.18\right)$ suggesting that nearly $12 \%$ of the original variance in ring widths can be directly attributed to ice storm severity. A model which includes ice storms may be written as follows:

$$
\begin{aligned}
\mathrm{RWI}= & 2.319-0.057 \mathrm{SEV}+0.012 \mathrm{CMT} \\
& +0.029 \mathrm{PAP}-0.027 \mathrm{CJLT} \\
& +0.015 \mathrm{CMP}+0.016 \mathrm{PNP}
\end{aligned}
$$

\section{)}

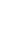


Table 3. Severity and timing of ice storms for Greensboro, Georgia, during the period 1926 to 1985

\begin{tabular}{|c|c|}
\hline Date & Severity \\
\hline 22 Dec 1929 & 1, minor \\
\hline 16 Dec 1932 & 1, minor \\
\hline 28 Dec 1935 & 4 , severe \\
\hline $7 \operatorname{Jan} 1940$ & 3 major \\
\hline 25 Dec 1945 & 2 moderate \\
\hline 2 Mar 1960 & 3, major \\
\hline $26 \operatorname{Jan} 1961$ & 2, moderate \\
\hline $25 \mathrm{Dec} 1962$ & 1, minor \\
\hline $11 \mathrm{Jan} 1970$ & 1, minor \\
\hline 25 Mar 1971 & 3. major \\
\hline $7 \mathrm{Jan} 1973$ & 1, minor \\
\hline 7 Feb 1979 & 4, severe \\
\hline $31 \mathrm{Jan} 1980$ & 2, moderate \\
\hline
\end{tabular}

where all variables are as described previously. For this pine stand, ice storm severity is the single most important variable. Temperature and precipitation and its timing through the year in combination account for more of the variance in ring widths. However, the addition of ice storm severity increased total explained variance from 35 to $46 \%$. No other variable produced such a large increase in accounted variance.

\section{Athens chronology}

Twenty-two loblolly pines were sampled near Athens; the trees provided a chronology for the period 1921 to 1986. Previous analysis of these data produced a simple model relating ring widths to monthly and seasonal temperature and precipitation (GrissinoMayer et al. 1989). Analysis of the raw data showed
Table 4. Severity and timing of ice storms for Athens, Georgia, during the period 1937 to 1986

\begin{tabular}{|rl|}
\hline \multicolumn{1}{|c|}{ Date } & Severity \\
\hline 7 Jan 1940 & 3, major \\
25 Dec 1945 & 2, moderate \\
2 Mar 1960 & 3, major \\
26 Jan 1961 & 1, minor \\
25 Dec 1962 & 1, minor \\
11 Jan 1970 & 1, minor \\
25 Mar 1971 & 2, moderate \\
7 Jan 1973 & 2, moderate \\
7 Feb 1979 Jan 1980 & 4, severe \\
\hline
\end{tabular}

their model to be the most parsimonious, and it was applied to this study as well. The model is:

$$
\mathrm{RWI}=2.08+0.015 \mathrm{GP}-0.019 \mathrm{GT}
$$

$\left(\mathrm{R}^{2}=0.39\right)$

where GP = precipitation total for the May-September period; and GT = June to September growing season average temperature.

Ten ice storms occurred in the Athens area during the study period 1937-1986 (Table 4). Seven of the 10 storms occurred during years in which a negative residual was produced by Eq. (5) (Fig. 4). Not surprisingly, the 2 greatest negative outliers (1979 and 1980) are associated with years in which ice storms occurred. Two other large outliers were produced in 1955 and 1967. Although no 'significant' ice storms occurred during these years, the climatic record shows that during March of both years, a severe, late winter freeze occurred. On both occasions this freeze was preceded

Fig. 3. Ring-width index residuals from

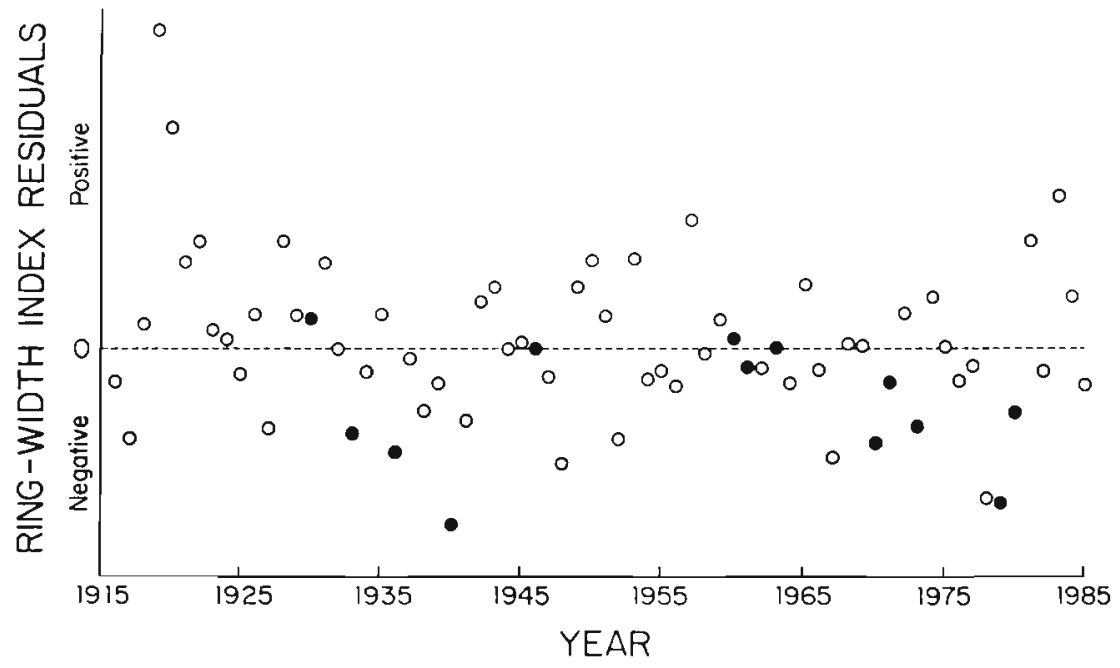
Eq. (3) (Greensboro, loblolly) 


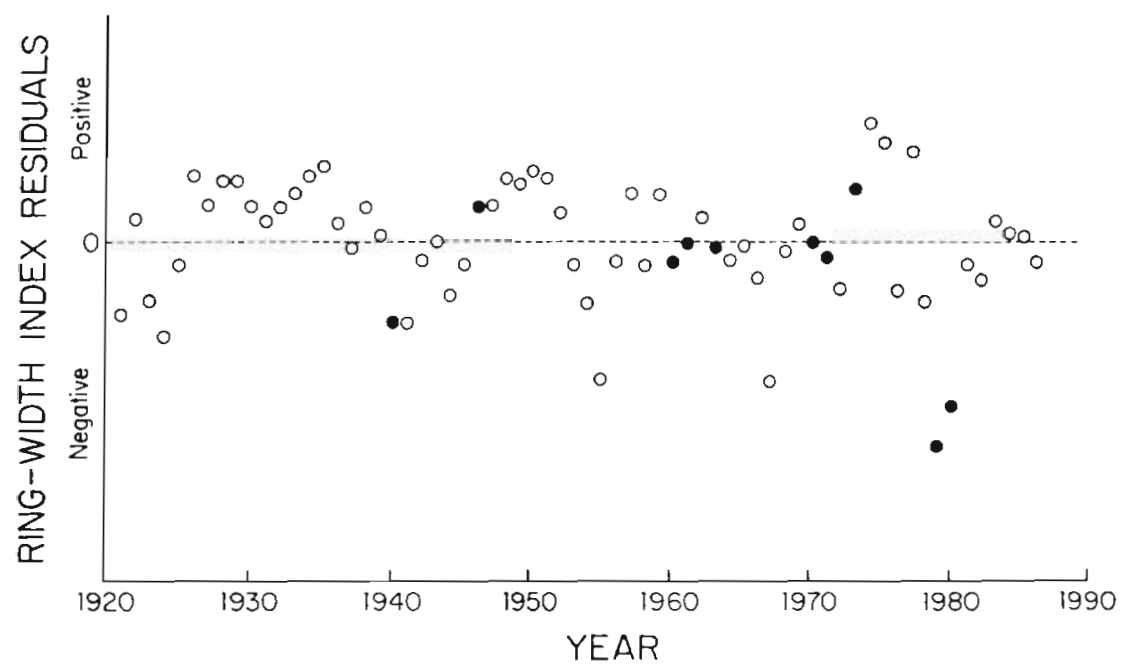

Fig. 4. Ring-width index residuals from Eq. (5) (Athens, loblolly)

by a very warm period which probably induced many trees to come out of dormancy early. Any initial bud growth may have been entirely damaged by the late freeze. If so, a significant reduction in earlywood growth could occur.

A regression of ice storm characteristics versus the ring-width residuals from Eq. (5) produced an $R^{2}$ of 0.22 , suggesting that as much as $13 \%$ of the original variance can be explained by ice storm influences. A final model was developed that incorporated both the influences of temperature and precipitation, and ice storm characteristics. The model is:

$$
\mathrm{RWI}=2.380+0.016 \mathrm{GP}-0.567 \mathrm{SEV}-0.023 \mathrm{GT}
$$

$$
\left(R^{2}=0.49\right)
$$

where all variables are as previously defined. The inclusion of ice storm severity increased the explanatory power of the original model from 39 to $49 \%$.

\section{DISCUSSION}

Ring-width indices showed a tendency to correlate strongly with precipitation during the growing season. This result is not surprising; previous research has shown that year-to-year variation in the growth of southern pines is most responsive to moisture stress (e.g. Phipps 1985). The average amount of explained variance in the 3 models is $33 \%$. Although slightly higher than values often reported, this mean value falls within the 17 to $41 \%$ range that is expected of dendroclimatic models for eastern North America (Dewitt \& Ames 1978).

Significant ice storms occurred at an average rate of once every $5 \mathrm{yr}$. This rate follows closely with those found by McKeller (1942) in this same region. The Appalachian Piedmont is a favorable region for ice storm development due to the shallow wedge of cold air that often flows south along the eastern side of the Appalachian mountains during the winter months.

An ice storm 'signal' is apparent in each of the 3 chronologies. In each a majority of the ice storms occurred during years in which a narrower than expected ring was produced. Most likely, the narrow rings were formed due to the loss of branches and needles which created less surface area for photosynthesis. Separate statistical analyses were performed to determine the duration of reduced ring increments by lagging the the second and third years following an ice storm. It is noteworthy that the damage is indeed temporary because only the immediate growing season appears to be affected by ice storms. Residuals from these models suggest that growth in rings can be more accurately predicted by monthly precipitation than by ice storms. Lost photosynthetic area is apparently replaced before the start of the second growing season.

All regression models using ice storm variables were significant. The addition of an ice storm variable (timing or severity) into each of the original temperature and precipitation models increased the average amount of explained variance for the 3 sites from 33 to $46 \%$. This confirms statistically and empirically the importance of ice storms to tree stem development. It is possible that the ice storm influences are even more pronounced than these results show because we used only trees that did not show the structural damage commonly found in these stands.

The statistical models also indicate no obvious difference in the strength of the ice storm signal between loblolly and shortleaf pine species. Although loblolly pines have longer needles and should therefore be more vulnerable, this factor may be offset by the fact 
that shortleaf pines have more needles per branch. As a result, total ice accumulation and damage may be similar.

\section{CONCLUSIONS}

The regression models presented here support the contention that the timing and severity of ice storms are important influences in the ring increment size of loblolly pine and shortleaf pine. In each model which included an ice storm variable, at least 1 of the 2 variables demonstrated significant explanatory power. It is interesting to note that 'severity' was critical to both loblolly chronologies, while 'timing' was important to the growth rates in the shortleaf chronology. This suggests that these species may actually be vulnerable in a separate fashion but responding in the same manner. Though none of the sampled trees showed visually the permanent structural damage which ice storms can create, they nevertheless did show reductions in ring widths. These results also suggest that it may be possible, by accounting for lost growth, to determine the economic impact of ice storms over the life of a tree. Future research should be directed to producing a better understanding of the way in which these episodic and apparently temporary influences enter into ring development.

Acknowledgements. The authors thank Mr Henri GrissinoMayer and Dr Roger Belanger for their help in the statistical and tree selection procedures of the study.

\section{LITERATURE CITED}

Baxter, D. V. (1943). Pathology in forest practice. Wiley, New York

Bennett, I. (1959). Glaze - its meteorology and climatology. U.S. Army Quartermaster Res. \& Eng. Cent., Environ. Prot. Res. Div. Tech. Rep. EP 105, 217 p.

Blasing, T. J., Duvick, D. N., West, D. C. (1981). Dendroclimatic calibration and verification using regionally averaged and single station precipitation data. Tree-Ring Bull. 41 : $37-43$

Editor: G. Esser
Box, G. E. P., Jenkins, G. H. (1976). Time series analysis, forecasting and control. Holden-Day, San Francisco

Brender, E. V., Romancier, R. M. (1960). Glaze damage in loblolly pine plantations. South. Lumberman 201(2513): 168

Dewitt, E., Ames, M. (1978). Tree-ring chronologies of eastern North America. Chronology Series IV, Vol. 1, Laboratory of tree-ring research. University of Arizona, Tucson

Fritts, H. C. (1976). Tree rings and climate. Academic Press, New York

Goebel, C. J., Deitschman, G. H. (1967). Ice storm damage to planted conifers in lowa. J. For. 65: 496-497

Grissino-Mayer, H., Rosenberger, M. S., Butler, D. R. (1989). Climate response in tree rings of loblolly pine from northern Georgia. Phys. Geog. 10(1): 32-43

Hebb, E. A. (1971). Resistance to ice damage - a consideration in reforestation. USDA For Serv. Tree Plant. Notes 22(2): 353-357

Hughes, M. K., Kelly, P. M., Pilcher, J. R., LaMarche, V. C. Jr (1982). Climate from tree rings. Cambridge University Press, Cambridge

Lawson, M. P., Heim, R. Jr, Mangimelli, J. A., Moles, G. (1980). Dendroclimatic analysis of bur oak in eastern Nabraska. Tree-Ring Bull. 40: 1-11

Lemon, P. C. (1961). Forest ecology of ice storms. Bull. Torrey Bot. Club 88(1): $21-29$

McKeller, A. D. (1942). Ice damage to slash pine, longleaf pine, and loblolly pine plantations in the Piedmont section of Georgia. J. For. 40: 794-797

Phipps, R. L. (1985). Collecting, preparing, crossdating, and measuring tree increment cores. Water Resources Investigations Report 85-4148, U.S. Geological Survey, $48 \mathrm{p}$.

Shepard, R. K. (1975). Ice storm damage to loblolly pine in northern Louisiana. J. For. 73: 420-423

Stokes, M. A., Smiley, T. L. (1968). An introduction to tree ring dating. University of Chicago Press, Chicago

Swetnam, T W. (1987). Western Spruce outbreaks in northern New Mexico: tree-ring evidence of occurrence and radial growth impacts from 1700 to 1983). In: Jacoby, G. C. Jr Hornbeck, J. W. (eds.) Proceedings of the International Symposium on Ecological Aspects of Tree-Ring Analysis U.S. Department of Energy, Publication CONF-8608144. p. $130-141$

Travis, D. J. (1989). The influence of ice storms on the growth rates of loblolly pine (Pinus taeda L.) and shortleaf pine (Pinus echinata Mill.) in the Appalachian Piedmont. M.A. thesis, Univ. of Georgia

Travis, D. J., Meentemeyer, V., Belanger, R. (1991). Stressed trees produce a better climate signal than healthy trees. Tree-Ring Bull. (in press)

Turner, D. W., Marriott, D. J. (1988). An unusual example of freezing rain. Meteorol. Mag. 117: 255-257

Manuscript first received: April 14, 1991

Revised version accepted: October 4, 1991 